\title{
Anti-protozoan activities of Harungana madagascariensis stem bark extract on trichomonads and malaria
}

\author{
E.O. Iwalewa, N.O. Omisore, C.O. Adewunmi, A.A. Gbolade, O.G. Ademowo, \\ C. Nneji, O.I. Agboola, O.M. Daniyan \\ Department of Pharmacology, Faculty of Pharmacy, Obafemi Awolowo University, Ile-Ife, \\ Nigeria \\ Department of Drug Research and Production Unit, Faculty of Pharmacy, Obafemi Awolowo \\ University, Ile-Ife, Nigeria \\ Department of Pharmacognosy, Faculty of Pharmacy, Obafemi Awolowo University, Ile-Ife, \\ Nigeria \\ Institute of Medical Research and Training, College of Medicine, University of Ibadan, \\ Ibadan, Nigeria \\ Department of Paraclincal Sciences (Phytomedicine Programme), Faculty of Veterinary \\ Sciences, University of Pretoria, PB 0X4, Onderstepoort 0110, Pretoria, South Africa
}

With 5 tables and 2 figures

\begin{abstract}
Aim of the study: The ethanolic stem bark extract of Harungana madagascariensis (Hypericaceae), (Choisy) Poir were evaluated for their activities on Trichomonas gallinae (Rivolta) Stabler isolated from the pigeon (Columba livia). It was also tested for their antimalarial activity on N67 Plasmodium yoelii nigeriensis (in vivo) in mice and on Plasmodium falciparum isolates in vitro.
\end{abstract}

Materials and methods: The anti-trichomonal screening was performed in vitro using Trichomonas gallinae culture. The minimum lethal concentration (MLC) is the lowest concentration of the test extract in which no motile organisms were observed. The antimalarial effects were determined in-vivo for suppressive, curative and prophylactic activities in mice receiving a standard inoculum size of $1 \times 10_{7}(0.2 \mathrm{ml})$ infected erythrocytes of Plasmodium yoelii nigeriensis intraperitoneally, and the in vitro was performed against 3 isolates of Plasmodium falciparum in a candle jar procedures.

Results: The $\mathrm{IC}_{50}$ of the extract and metronidazole (MDZ) (Flagyl) on Trichomonas gallinae at $48 \mathrm{~h}$ are 187 and $1.56 \mu \mathrm{g} / \mathrm{ml}$. The $\mathrm{IC}_{50}$ of the extract, chloroquine (CQ) and artemether (ART) on Plasmodium falciparum are between 0.052 and $0.517 \mu \mathrm{g} / \mathrm{ml}$ for the extract and 0.021 and $0.0412 \mu \mathrm{g} / \mathrm{ml}$ for ART and CQ, respectively. The actions of the extract in in vivo study on Plasmodium yoelii nigeriensis showed that in both suppressive and prophylactic tests the percentages chemo-suppressive were between $28.6-44.8 \%$ and $30.2-78.2 \%$ respectively, while only $80 \mathrm{mg} / \mathrm{kg}$ of the extract reduced the parasitaemia level when compared to the control and the standard drugs in curative test.

Conclusions: Harungana madagascariensis stem bark extract therefore exhibited significant anti-protozoan effects against Trichomonas and Plasmodium both in vivo and in vitro.

Keywords: Anti-malarial; Anti-trichomonal; Harungana madagascariensis; Stem bark extract; In vivo and in vitro studies

\section{Introduction}

\subsection{Plant}

Harungana madagascariensis (Choisy) Poir. (Hypericaceae) is otherwise called dragon's blood tree. The genus is monotypic, the single species being found in tropical Africa, Madagascar, Mauritius and Mascareigne Island. The local names are "Amuje", "Aroje", and "Arunje". It is widespread and locally abundant in areas where annual rainfall exceeds 1300mm. (Hutchinson and Dalziel, 1954; Humphries and Stanton, 1992; Csurhes and Edwards, 1998). The fresh stem barks of Harungana madagascariensis were collected along 
Ede and Ondo roads near the main University campus, lle-lfe. The plant was identified by Mr. O.A. Oladele of the Department of Pharmacognosy, Faculty of Pharmacy, Obafemi Awolowo University, Ile-Ife and a voucher specimen with voucher number FHI 107392 was kept at the herbarium of the Forestry Research Institute of Nigeria, Ibadan.

\subsection{Previously isolated classes of constituents}

Some of the constituents and isolated compounds from Harungana madagascariensis includes: flavonoids, alkaloids, saponins, glycosides, and tannins (Moulari et al., 2006a,b). Three prenylated anthranoids: harunmadagascarins $C$ and $D$ and kenganthranol $D$, three prenylated 1,4-anthraquinone: harunmadagascarins $\mathrm{A}$ and $\mathrm{B}$, harunganol $\mathrm{B}$ and harungin anthrone (Kouam et al., 2006a,b, 2007), Bazouanthrone, a newanthrone derivative, has been isolated from the root bark of Harungana madagascariensis, together with other known compounds, feruginin $A$, harunganin, harunganol $A$, harunganol $B$, friedelan-3-one and betulinic acid (Ndjakou Lenta et al., 2007).

\subsection{Uses in traditional medicine}

Traditionally, the leaves and stem bark are used for the treatment of anaemia, the stem bark is also used for nephrosis, malaria, gastro-intestinal disorders and fever (EMEA, 1999; Tona et al., 2000; Erah et al., 2003; Kamanzi Atindehou et al., 2004). Aqueous leaf extract has been shown to have anti-microbial activity on different strains of bacteria (Bacillus subtilis, Staphylococcus aureus, Eschericia coli and Salmonella typhi), thus substantiating its use for gastro-intestinal disorders (Okoli et al., 2002). The stem bark extract inhibited Entamoeba hystolytica growth at a concentration of less than $10 \mu \mathrm{g} / \mathrm{ml}$ (Tona et al., 2000). The stem bark extract also exhibited more than $70 \%$ inhibition of acetylcholine and potassium chloride solution-induced contractions on isolated guinea-pig ileum. Harungana madagascariensis is a component of Jubi Formula, an herbal preparation which was found to restore the pack cell volume $(\mathrm{PCV})$ and haemoglobins $(\mathrm{Hb})$ concentration in anaemia conditions and is a potential substitute for blood transfusion (Erah et al., 2003). Lukwa et al. (2001) made an ethnobotanical survey on some herbal remedies used by traditional healers in Mola, Kariba district of Zimbabwe for the treatment and prevention of malaria, Harungana madagascariensis is one of the plants used for the treatment of malaria. Earlier studies of Harungana madagascariensis were based on the leaves, (Madubunyi et al., 1995; Kamanzi Atindehou et al., 2004; Okoli et al., 2002; Moulari et al., 2006a,b; Kouam et al., 2007). Nwodo (1989) and Kouam et al. (2006a,b) have, however, examined the effect of crude extracts and isolated compounds from a hexane extract of the stem bark of Harungana madagascariensis, for their analgesic, anti-inflammatory, alpha-glucosidase inhibition and anti-oxidant activities respectively. The most recent work of Ndjakou Lenta et al. (2007) showed the anti-plasmodial effects of six isolated compounds from the root bark of Harungana madagascariensis in vitro. Many isolated compounds from natural products have been tested in vitro for anti-malarial properties; and found to exhibit potent activities (Rukunga and Simons, 2006). Studies have shown that in vivo examinations of the same compounds are without such activities (Khalid et al., 1989; Bray et al., 1990). To complement these studies, we therefore, investigated the activities of Harungana madagascariensis stem bark on Trichomonas gallinae (in vitro) and malaria (in vivo and in vitro), in order to authenticate its efficacy in traditional medicine.

\section{Materials and methods}

\subsection{Plant materials and preparation of the extracts}

The ethanolic extraction was made by soaking $325 \mathrm{~g}$ of the dried powdered stem bark in 70:30 ethanol:water for $24 \mathrm{~h}$. After maceration, the extract was evaporated in vacuo in a rotary evaporator to dryness, yielding $9 \mathrm{~g}$ of the brown crude extract.

\subsection{Parasites}

Trichomonas gallinae was obtained from the gut of a local pigeon bred and maintained in the Drug Research and Production Unit. The N 67 chloroquine (CQ) sensitive strain of Plasmodium yoelii nigeriensis was donated generously by the Malaria Research and Reference Reagent Resource Center (MR4) Manassas, VA, USA, and was obtained from the Institute of Medical Research and Training courtesy of Dr. O.G. Ademowo. The Plasmodium 
falciparum was obtained from the patients that visited Clinical Pharmacology Unit, University Teaching Hospital, College of Medicine, Ibadan.

\subsection{Animals}

Mice of either sex, weighing between 18 and $220 \mathrm{~g}$ were used. The animals were maintained at $25+1{ }^{\circ} \mathrm{C}$ under natural $12 \mathrm{~h}$ daylight/night conditions for at least 5 days before the experiment. All the animals were fed with standard diet in the Department of Pharmacology Animal House and water was given ad libitum.

The "principle of laboratory animal care" (National Institute of Health-NIH publication No. 8523) guidelines and procedures were followed in this study ( $\mathrm{NIH}$ publication revised, 1985).

\subsection{Anti-trichomonal test}

Trichomonas gallinae was cultured in Ringer-Egg-Serummedium according to the method of Boeck and Drbolav (1925) as cited by Levine (1961). The anti-trichomonal screening was performed in vitro according to the method of Meingasser and Thurner (1979) as reported by Oyedapo et al. (2004). Trichomonas culture was distributed into micro well plates and solutions of the test substances were added to make concentrations of 250, 500, 1000, 2000 and $4000 \mu \mathrm{g} / \mathrm{ml}$.Metronidazole (MDZ) was used as reference substance in the following concentrations: $0.62,1.25,2.5,5,10$ and $20 \mu \mathrm{g} / \mathrm{ml}$. $50 \mu \mathrm{l}$ of extract and $150 \mu \mathrm{l}$ of the culture solution were pipetted into the micro wells and incubated at $37 \mathrm{C}$ for 24 and $48 \mathrm{~h}$. Wet mount microscopic observation was done for each time set. The experiments were done in triplicates. The minimum lethal concentration (MLC) is the lowest concentration of the test extract in which no motile organisms were observed. A graph of \% inhibition of parasites growth against the concentration of the extract and the standard agents were plotted and the $\mathrm{IC}_{50}$ (the inhibitory concentration that suppressed the growth of the parasites population by $50 \%$ ) were extrapolated.

\subsection{Anti-malarial tests}

The anti-malarial effects were determined according to Peters and Robinson (1992), Ryley and Peters (1970) and Peters (1965), respectively for suppressive, curative and prophylactic tests, and the in vitro was performed according to WHO (1987).

The evaluation of blood schizonticidal activity on an early suppressive infection (4-day test), prophylactic and curative tests The blood schizonticidal activity of the extracts $(20,40$ and 80 $\mathrm{mg} / \mathrm{kg} /$ day); chloroquine $(5 \mathrm{mg} / \mathrm{kg} /$ day) as standard drug and normal saline $(0.9 \%)$ as control were assessed in parasitized albino mice receiving a standard inoculum size of $1 \times 10^{7}(0.2 \mathrm{ml})$ infected erythrocytes of Plasmodium yoelii nigeriensis intraperitoneally on day zero. In the suppressive test, the administration of drugs took place from Day 0 to Day 3. On Day 4, blood smears were made from the tail of the mouse and percentage parasitemia determined. In prophylactic test, another group of animals were first treated with the extracts and pyrimethamine $(1.2 \mathrm{mg} / \mathrm{kg})$ daily for 3 days, and were inoculated with parasites after treatment, $72 \mathrm{~h}$ after infection, parasitaemia were determined. However in curative test, the animals were infected with same parasites and were allowed to be established for $72 \mathrm{~h}$ after which treatment was given for 5 days and parasitaemia was determined.

\subsection{In vitro method}

The extract $(10 \mathrm{mg})$ was weighed and dissolved in $0.5 \mathrm{ml}$ of sterile distilled water to give a stock concentration of $5 \mathrm{mg} / \mathrm{ml}$. Chloroquine and artemether (ART) stock concentration were $0.5 \mathrm{mg} / \mathrm{ml}$. From these stock solutions, a 10-fold dilution was made with RPMI 1640 medium (without bicarbonate). $100 \mu \mathrm{l}$ aliquots of diluted extract dispensed into 96-well plates gave $0.07,0.21,0.62,1.85,5.60,16.7$, and $50.0 \mu \mathrm{g} / \mathrm{ml}$ as final concentration, while $\mathrm{CQ}$ and ART gave 10 times lower than that of the extract. Fifty microlitres of RPMI 1640 medium plus bicarbonate and serum $A_{+}$as complete serum were aliquoted into all the wells. Twenty-five microlitres of infected red cell of each isolates were separately added. The starting parasitaemia was between $2.5-5.0 \%$. However, the negative controls were without the extract. After this, the plates were covered, shaken gently and incubated in a desiccator at 37 ${ }^{\circ} \mathrm{C}$ for 27-30 h. After incubation, the contents of both the controls and tested wells were harvested and the deposited red cells were transferred to a slide to form a thick film. The film 
was dried and stained with Giemsa and the parasites were assessed for growth. The numbers of schizonts with three or more nuclei out of a total of 200 asexual parasites were noted. A graph of \%inhibition of parasites growth against the concentration of the extract and the standard agents were also plotted and the $\mathrm{IC}_{50}$ were determined.

\subsection{Data and statistical analysis}

Data are expressed as mean \pm S.E.M. and analyzed using one way analysis of variance (ANOVA) followed by Dunnett Test for comparing pairs of data. The significant level was set at $p<0.05$. The $\mathrm{IC}_{50}$ values were calculated using the Microsoft Excel program.

\section{Results}

Results of the anti-protozoan activity of HMSE on trichomonads and malaria parasites showed an inhibitory effect on the parasites growth. The in vitro activities were expressed in Tables 1 and 2; Figs. 1 and 2. The IC50 of the extract and MDZ (Flagyl) on Trichomonas gallinae at 24 and $48 \mathrm{~h}$ are 1000.0 and $1.87 \mu \mathrm{g} / \mathrm{ml}$ at $24 \mathrm{~h}$ and 187.0 and $1.56 \mu \mathrm{g} / \mathrm{ml}$ at $48 \mathrm{~h}$, respectively. The $\mathrm{IC}_{50}$ of the extract, $\mathrm{CQ}$ and $\mathrm{ART}$ on Plasmodium falciparum are between 0.052 and $0.517 \mu \mathrm{g} / \mathrm{ml}$ for the extract and 0.021 and $0.0412 \mu \mathrm{g} / \mathrm{ml}$ for ART and CQ respectively. The actions of the extract in in vivo study on Plasmodium yoelii nigeriensis were indicated in Tables 3-5. In both suppressive and prophylactic tests the percentage chemosuppressive was between $28.6-44.8 \%$ and $30.2-78.2 \%$, respectively. However, in curative test, only $80 \mathrm{mg} / \mathrm{kg}$ of the extract reduced the parasitaemia level as compared to the control and the standard drugs.

\section{Discussion}

Plants are often considered to be useful against infectious diseases, which are used as alternatives to synthetic compounds without regard to different etiological agents (viral, bacterial, fungus and protozoa) in traditional medical practice. The wide reports of Harungana madagascariensis plant parts that are used in various infectious disorders points to the fact that the plant constituents could be potential anti-infective candidates for the treatment of viral, bacteria, fungi, and protozoa (Madubunyi et al., 1995; Okoli et al., 2002; Kamanzi Atindehou et al., 2004;Moulari et al., 2006a,b; Kouam et al., 2007).

Our experiments demonstrate that phyto-chemical constituents present in the stem bark extract of Harungana madagascariensis used in traditional medicine to treat infectious diseases, exhibited anti-protozoan activity against Trichomonas gallinae in vitro and Plasmodium parasites both in vivo and in vitro. This however, supports the reports of Gessler et al. (1995), Tona et al. (2000) and Ndjakou Lenta et al. (2007) that showed the leaves and root bark extracts from Harungana madagascariensis, which inhibited another protozoan Entamoeba hystolytica growth in an investigation on the putative anti-amoebic and Plasmodium falciparum isolates respectively. Although, anti-protozoan effects of different parts (leaves, seeds and root extracts) of Harungana madagascariensis have been evaluated by various authors (Tona et al., 2000; Kamanzi Atindehou et al., 2004 and Ndjakou Lenta et al., 2007), no activity on the stem bark or any part of the plant have been reported in vivo. All the works cited are in vitro studies. In addition, other forms of protozoa (amoebasis, leishmaniasis, trypanosomiasis) have been tested against different extracts of this plant, while trichomonads remain the only protozoa. These two reasons prompted the objective of this study.

Trichomoniasis and malaria have important medical, social and economic implications. Premature labour, premature ruptures of placental membranes and low birth-weights have been reported in infected pregnant women. $T$. vaginalis can augment the predisposition of individuals to human immunodeficiency viruses (HIV) (Petrin et al., 1998). Metronidazole is the recommended treatment for trichomoniasis. Tinidazole (Fasigyn) is an alternative drug. Adverse reactions to high doses and also allergic reactions to metronidazole have been reported (Narcisi and Secor, 1996). Multiple drug resistances to these routine drugs are on the increase, it has been shown that $5 \%$ of the population has shown resistance to metronidazole (Lossick, 1989) and the frequency of chloroquine resistance ranged from $18 \%$ to $62 \%$ (Rowland et al., 1997). 
This problem of resistance alone is enough to search for new agents from plants used in traditional medicine for the treatment of these ailments (Rukunga and Simons, 2006).

The activity of the extract on trichomonads is weak compared to metronidazole. However, the $I_{50}$ of the extract at $48 \mathrm{~h}$ was highly reduced; an indication that the extract contact time with the parasite is a factor for its effectiveness. On malaria parasites also, the $\mathrm{IC}_{50}$ of the extract was highly comparable with that of chloroquine and artemether, however, the positive control drugs are 10 times more potent than the extract against the two parasites tested. Rukunga and Simons (2006) classified the in vitro activity of natural products having anti-plasmodial effects into three categories. The first category deals with plant extracts exhibiting high antiplasmodial action $\left(\mathrm{IC}_{50}\right.$ less than or equal to $\left.10 \mu \mathrm{g} / \mathrm{ml}\right)$. The second groups are moderately active with $I_{50}$ greater than 10 but less than $100 \mu \mathrm{g} / \mathrm{ml}$, while the third category was termed as low active group as their $\mathrm{IC}_{50}$ is greater than $100 \mu \mathrm{g} / \mathrm{ml}$. The results of this study fall in the first category indicating that the extract has a high anti-plasmodial activity against malaria, but exhibited weak effect on trichomonads. These observations indicated that a difference in the parasites genus has an effect on the response to the test substance. In the three models of malaria treatment employed in our in vivo study, the results showed that the extract also inhibited the multiplication of malaria parasites in rodents in various degrees. It was clearly shown that the extract had no significant effect in curative treatment, but is highly effective through suppressive and prophylactic mode of therapy. This could therefore be the mode of treatment employed in traditional medicine. Many compounds from natural products have been shown to exhibit potent in vitro anti-malarial activities (Rukunga and Simons, 2006). However, various studies have indicated that in vivo examinations of the same compounds are without such activities (Khalid et al., 1989 and Bray et al., 1990).

Till date no single report is available on the in vivo effect of the stem bark extract against Plasmodium in rodents. The current study reports for the first time, the in vivo efficacy of the plant to justify the traditional uses against malaria and Trichomonas gallinae as anti-protozoal agent. These activities on malaria and trichomonads pathogens like those reported against fungi and bacteria organisms could then explain the usefulness of the plant in the treatment of fever, tuberculosis, diarrhea, dysentery, syphilis, gonorrhea, parasitic skin diseases and wounds. From the phytochemical studies, anthraquinone, anthranoids, courmarins, and triterpenoids are the compounds that were detected. The Hypericaceae family is well known for the production of various phenolic compounds such as anthraquinones, xanthones, coumarins, biflavonoids and anthrone derivatives (linuma et al., 1995) which are known to exhibits antimicrobial activities (Rabanal et al., 2002). It is possible that these bioactive compound(s) found in the stem bark could be responsible for these activities.

\section{Conclusion}

Harungana madagascariensis stem bark extract had significant anti-trichomonal and antimalarial activities thus indicating their positive role, and justifying the ethnomedicinal use of the plant parts in traditional medicine.

\section{References}

1. Boeck,W.C., Drbolav, J., 1925. Laboratory culture of protozoal parasites. Proceedings of National Academy of Sciences 11, 235-238.

2. Bray, D.H., Warhurst, D.C., Connolly, J.D., O'Neill, M.J., Phillipson, J.D., 1990. Plants as sources of antimalarial drugs. Part 7. Activity of some species of meliaceae plants and their constituent limonoids. Phytotherapy Research 4, 29-35.

3. Csurhes, S., Edwards, R., 1998. Potential Environmental Weeds in Australia: Candidate Species for Preventative Control. Queensland Department of Natural Resources, p. 109.

4. EMEA, 1999. Committee for Veterinary Medicinal Products - Harunga madagascariensis Summary Report - The European Agency for the Evaluation of Medicinal Products, VeterinaryMedicines Evaluation Units. EMEA/MRL/598/99FINAL.

5. Erah, P.O., Asonye, C.C., Okhamafe, A.O., 2003. Response of Trypanosoma brucei brucei-induced anaemia to a commercial herbal preparation. African Journal of Biotechnology 2, 307-311. 
6. Gessler, M.C., Tanner, M., Chollet, J., Nkunya, M.H.H., Heinrich, M., 1995. Tanzanian medicinal plants used traditionally for the treatment of malaria: in vivo antimalarial and in vitro cytotoxic activities. Phytotherapy Research 9, 504-508.

7. Humphries, S.E., Stanton, J.P., 1992. Weed assessment in the wet tropics world heritage area of north Queensland. Report to theWet Tropics Management Agency, pp. 25-26.

8. Hutchinson, J., Dalziel, J.M., 1954. Flora ofWest Tropical Africa, Part 1, vol. 1. Crown Agents, London, p. 290.

9. linuma, M., Hideki, T., Tetsuro, I., Toshiyuki, T.,Mohammad, A., 1995. Two prenylated anthrones in Harungana madagascariensis. Phytochemistry 40, 267-270.

10. Levine, N.D., 1961. Laboratory diagnosis of protozoan infections. In: Protozoan Parasites of Domestic Animals and Man. Burgess Publishing Co., Minneapolis, pp. 377-393.

11. Lossick, J.G., 1989. Therapy of urinogenital Trichomoniasis. In: Honigberg, B.M. (Ed.), Trichomonads Parasitic in Man. Springer Verlag, New York, pp. 324-341.

12. Lukwa, N.,Mutambu, S.L., Makaza, N.,Molgaard, P., Furu, P., 2001. Perceptions about malaria transmission and control using anti-malaria plants inMola, Kariba, Zimbabwe. Nigerian Journal of Natural Products and Medicine 5, 4-7.

13. Kamanzi Atindehou, K., Schmid, C., Brun, R., Kone, M.W., Traore, D., 2004. Antitrypanosomal and antiplasmodial activity of medicinal plants from Côte d'Ivoire. Journal of Ethnopharmacology 90, 221-227.

14. Khalid, S.A., Duddeck, H., Gonnzalez-Sierra,M., 1989. Isolation and characterization of an antimalarial agent of the neem tree Azadirachta indica. Journal of Natural Products 52, 922-926.

15. Kouam, S.F., Khan, S.N., Krohn, K., Ngadjui, B.T., Lapche, D.G., Yapna, D.B., Zareem, S., Moustafa, A.M., Choudhary, M.I., 2006a. Alpha-glucosidase inhibitory anthranols, kenganthranols $\mathrm{A}-\mathrm{C}$, from the stem bark of Harungana madagascariensis. Journal of Natural Product 69, 229-233.

16. Kouam, S.F., Ngadjui, B.T., Krohn, K., Wafo, P., Ajaz, A., Choudhary, M.I., 2006b. Prenylated anthronoid antioxidants from the stem bark of Harungana madagascariensis. Brazillian Journal of Medical and Biological Research 38, 10871094.

17. Kouam, S.F.,Yapna, D.B., Krohn, K.,Ngadjui, B.T.,Ngoupayo, J., Choudhary, M.I., Schulz, B., 2007. Antimicrobial prenylated anthracene derivatives from the leaves of Harungana madagascariensis. Journal of Natural Products 70, 600-603.

18. Madubunyi, I.I., Obi, S.K.C., Nwebube, N.I., Chime, A.B., 1995. Antihepatotoxic and antimicrobial activities of Harungana madagascariensis leaf extracts. International Journal of Pharmacognosy 33, 129-134.

19. Meingasser, J.G., Thurner, J., 1979. Strain of Trichomonas vaginalis resistant tometronidazole and other 5-nitroimidazoles. Antimicrobial Agents and Chemotherapy 15, 254-257.

20. Moulari, B., Lboutounne, H., Chaumont, J.-P., Guillaume, Y., Millet, J., Pellequer, Y., 2006a. Potentiation of the bactericidal activity of Harungana madagascariensis Lam. ex Poir. (Hypericaceae) leaf extract against oral bacteria using poly(d,I-lactide-coglycolide) nanoparticles: in vitro study. Acta Odontologica Scandinavica 64, 153-158.

21. Moulari, B., Pellequer,Y., Lboutounne, H., Girard, C., Chaumont, J.-P., Millet, J.,Muyard, F., 2006b. Isolation and in vitro antibacterial activity of astilbin, the bioactive flavanone from the leaves of Harungana madagascariensis Lam. ex Poir. (Hypericaceae) Journal of Ethnopharmacology 106, 272-278.

22. Narcisi, E.M., Secor, W.E., 1996. In vitro effect of Tinidazole and Furazolidone on metronidazole-resistant Trichomonas vaginalis. Antimicrobial Agents Chemotherapy 40, 1121-1225.

23. Ndjakou Lenta, B., Ngouela, S., Fekam Boyom, F., Tantangmo, F., Feuya Tchouya, G.R., Tsamo, E., Gut, J., Rosenthal, P.J., Donald Connolly, J., 2007. Anti-plasmodial activity of some constituents of the root bark of Harungana madagascariensis LAM. (Hypericaceae) Chemical and Pharmaceutical Bulletin 55, 464-467.

24. Nwodo, O.F.C., 1989. Antibiotic and anti-inflammatory analgesic activities of Harungana madagascariensis stem bark. International Journal of Crude Drug Research 27, 137-140. 
25. Okoli, A.S., Okeke, M.I., Iroegbu, C.U., Ebo, P.U., 2002. Antibacterial activity of Harungana madagascariensis leaf extract. Phytotherapy Research 16, 174-179.

26. Oyedapo, O.A., Adewunmi, C.O., Makanju, V.O., Iwalewa, E.O., Adenowo, T.K., 2004. Antitrichomonal activities of synthetic 1,3-diaryl-2-propen-1-ones on Trichomonas gallinae. African Journal of Traditional, Complimentary and Alternative Medicine 1, 55-62.

27. Peters, W., 1965. Drug resistance in Plasmodium berghei. Venke and Lips (1948). I. Chloroquine resistance. Experimental Parasitology 17, 80-87.

28. Peters,W., Robinson, B.L., 1992. The chemotherapy of rodent malaria. XLVII. Studies on pyronaridine and other Mannich base antimalarials. Annal Journal of Tropical Medicine and Parasitology 86, 455-465.

29. Petrin, D., Delgaty, K., Bhatt, R., Garber, G., 1998. Clinical Microbiology Reviews 11, 300-317.

30. Rabanal, R.M., Arias, A., Prado, B., Herna'ndez-Pe' rez, M., Sa'nchez-Mateo, C.C., 2002. Antimicrobial studies on three species of Hypericum from the Canary Islands. Journal of Ethnopharmacology 81, 287-292.

31. Rowland, M., Durrani, N., Hewitt, S., Sondorp, E., 1997. Resistance of falciparum malaria to chloroquine and sulfadoxine-pyrimethamine in Afghan refugee settlements in western Pakistan: surveys by the general health services using a simplified in vivo test. Tropical Medicine of International Health 2, 1049-1056.

32. Rukunga, G., Simons, A.J., 2006. The Potential pf Plants as a Source of Antimalarial Agents-A Review. Africa Herbal Antimalarial Meeting CDE and ICRAF, Nairobi, p. 9.

33. Ryley, J.F., Peters,W., 1970. The antimalarials of some quinoline esters. Annal Journal of Tropical Medicine and Parasitology 84, 209.

34. Tona, L., Kambu, K., Ngimbi, N., Mesia, K., Penge, O., Lusakibanza, M., Cimanga, K., De Bruyne, T., Apers, S., Totte, J., Pieters, L., Vlientinck, A.J., 2000. Antiamoebic and spasmolytic activities of extracts from some antidiarrhoeal traditional preparations used in Kinshasa, Congo. Phytomedicine 7, 31-38.

35. World Health Organization, 1987. In vitro micro test (mark II) for the assessment of the response of Plasmodium falciparum to Chloroquine Mefloquine, Quinine, Sulphadoxine-Pyrimethamine and Amodiaquine. W.H.O. mimeographed doc. No. MAP/87.2.

\section{Table 1}

An in vitro anti-trichomonads activity of metronidazole (MDZ) as positive control, and the stem bark (HMSE) extract of Harungana madagascariensis on Trichomonas gallinae (24 and $48 \mathrm{~h}$ ) Percentage of the number of surviving trichomonads (\%mortality/inhibition of Trichomonas gallinae growth)

\begin{tabular}{|c|c|c|c|c|}
\hline Concentration $(\mu \mathrm{g} / \mathrm{ml})$ & $24 \mathrm{~h}$ & & $48 \mathrm{~h}$ & \\
\hline & Flagyl MDZ & HMSE & Flagyl MDZ & HMSE \\
\hline 0 & 0.0 & 0.0 & 0.0 & 0.0 \\
\hline 0.62 & $11.1 \pm 5.5$ & - & $28.2 \pm 1.3$ & - \\
\hline 1.25 & $25.1 \pm 4.6$ & - & $38.0 \pm 1.9$ & - \\
\hline 2.5 & $94.4 \pm 2.5$ & - & $95.5 \pm 3.6$ & - \\
\hline 5.0 & 100.0 & - & 100.0 & - \\
\hline 10 & 100.0 & - & 100.0 & - \\
\hline 20 & 100.0 & - & 100.0 & - \\
\hline 250 & ND & $14.6 \pm 2.2$ & ND & $66.2 \pm 1.5$ \\
\hline 500 & ND & $33.4 \pm 2.6$ & ND & $76.1 \pm 0.7$ \\
\hline 1000 & ND & $48.1 \pm 3.8$ & ND & $84.3 \pm 0.9$ \\
\hline 2000 & ND & $88.8 \pm 0.9$ & ND & $97.6 \pm 0.3$ \\
\hline 4000 & ND & 100.0 & $\mathrm{ND}$ & 100.0 \\
\hline
\end{tabular}

ND: not determined. 


\section{Table 2}

The anti-trichomonads and anti-malarial IC50 values of the extract of Harungana madagascariensis and standard drugs-metronidazole, chloroquine and artemether on both trichomonads and malarial parasites (in vitro)

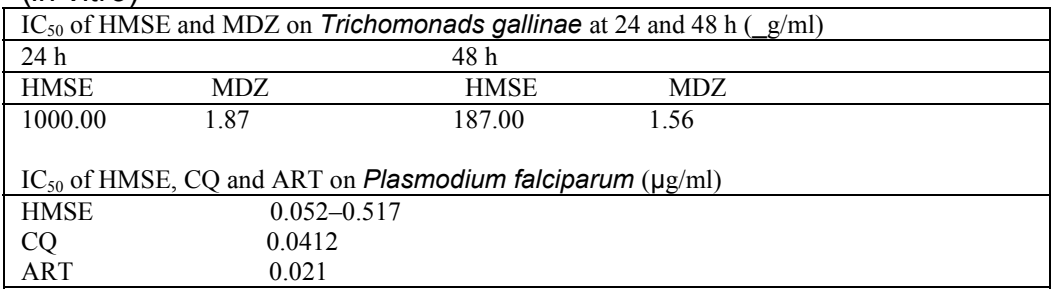

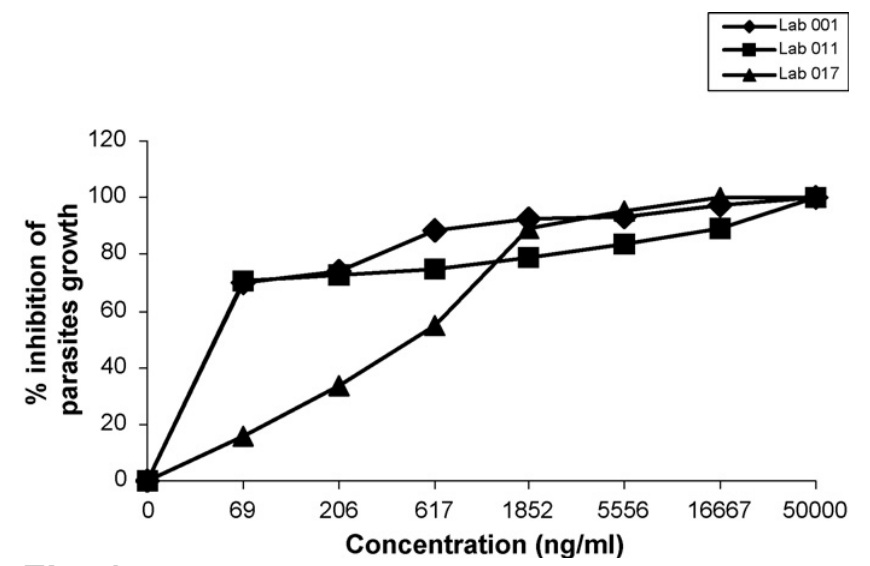

Fig. 1. In vitro effects of Harungana madagascariensis extract on Plasmodium falciparum. \%Inhibition of parasite growth against the various concentrations of the stem bark extract of Harungana madagascariensis (HMSE) on Plasmodium

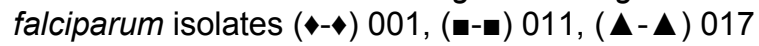

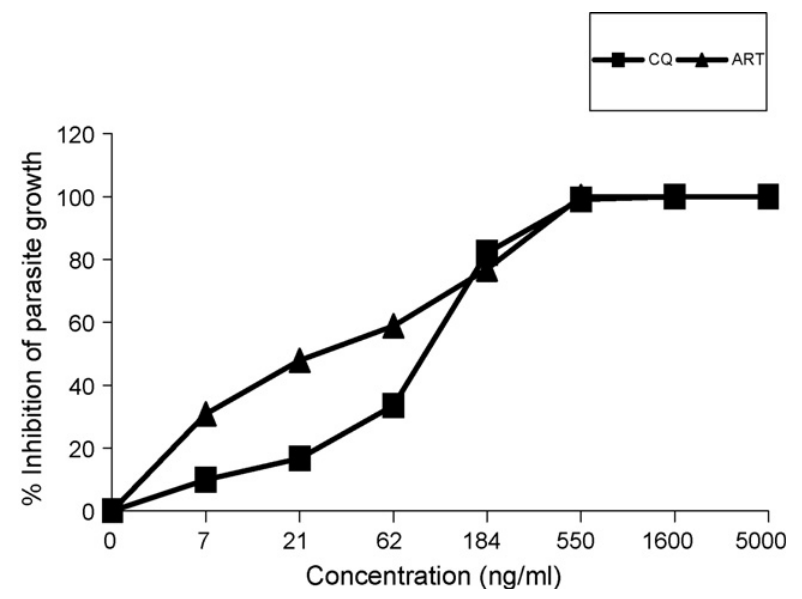

Fig. 2. In vitro effects of chloroquine (CQ) and artemether (ART) against Plasmodium falciparum isolates. \%Inhibition of parasite growth against the various concentrations of the standard drugs chloroquine (CQ) ( $\mathbf{-}-\mathbf{m})$ and artemether (ART) ( $\mathbf{\Delta}$ - $\mathbf{\Delta})$ on Plasmodium falciparu isolate. 


\section{Table 3}

The suppressive (in vivo) activity of the stem bark (HMSE) extract of Harungana madagascariensis and chloroquine (CQ) on Plasmodium yoelii nigeriensis

\begin{tabular}{|llc|}
\hline & Suppressive test & \\
\hline & \%Parasiteamia & \%Chemo-supression \\
\hline Control & $34.65 \pm 1.31$ & - \\
$20 \mathrm{mg} / \mathrm{kg}$ & $24.75 \pm 2.25^{\mathrm{a}, \mathrm{b}}$ & 28.57 \\
$40 \mathrm{mg} / \mathrm{kg}$ & $21.84 \pm 1.61^{\mathrm{a}, \mathrm{b}}$ & 36.99 \\
$80 \mathrm{mg} / \mathrm{kg}$ & $19.14 \pm 1.07^{\mathrm{a}, \mathrm{b}}$ & 44.76 \\
$\mathrm{CQ}(5 \mathrm{mg} / \mathrm{kg})$ & $10.2 \pm 0.3^{\mathrm{a}}$ & 70.56 \\
\hline
\end{tabular}

Values are mean \pm S.E.M., $n=5 ;{ }^{*} p<0.05$ vs. control.

a Significantly different from control at $p<0.05$.

${ }^{\mathrm{b}}$ Significantly different from $\mathrm{CQ}$ at $p<0.05$

\section{Table 4}

The prophylactic (in vivo) activity of the stem bark (HMSE) extract of Harungana madagascariensis and pyrimethamine (PYR) on Plasmodium yoelii nigeriensis

\begin{tabular}{|lcc|}
\hline \multicolumn{3}{|c|}{ Prophylactic test } \\
\hline & \%Parasiteamia & \%Chemo-supression \\
\hline Control & $15.35 \pm 0.12$ & - \\
$20 \mathrm{mg} / \mathrm{kg}$ & $10.71 \pm 0.81^{\mathrm{a}, \mathrm{b}}$ & 30.22 \\
$40 \mathrm{mg} / \mathrm{kg}$ & $4.96 \pm 0.83^{\mathrm{a}, \mathrm{b}}$ & 67.69 \\
$80 \mathrm{mg} / \mathrm{kg}$ & $3.35 \pm 0.77^{\mathrm{a}, \mathrm{b}}$ & 78.16 \\
Pyrimethamine $(1.2 \mathrm{mg} / \mathrm{kg})$ & $8.70 \pm 0.53^{\mathrm{a}}$ & 43.32 \\
\hline
\end{tabular}

Values are mean \pm S.E.M., $n=5 ;{ }^{*} p<0.05$ vs. control.

${ }^{a}$ Significantly different from control at $p<0.05$.

${ }^{\mathrm{b}}$ Significantly different from PYR at $p<0.05$.

\section{Table 5}

The curative (in vivo) activity of the stem bark (HMSE) extract of Harungana madagascariensis and chloroquine (CQ) on Plasmodium yoelii nigeriensis

\begin{tabular}{|c|c|c|c|}
\hline & \multicolumn{3}{|c|}{ Curative test (\%Parasitaemia) } \\
\hline & D7 & D9 & D11 \\
\hline Control & $13.5 \pm 0.88$ & $21.65 \pm 1.41$ & $22.12 \pm 2.75$ \\
\hline $20 \mathrm{mg} / \mathrm{kg}$ & $17.10 \pm 1.09^{\mathrm{a}, \mathrm{b}}$ & $21.78 \pm 1.52$ & $32.0 \pm 1.36^{\mathrm{a}, \mathrm{b}}$ \\
\hline $40 \mathrm{mg} / \mathrm{kg}$ & $15.94 \pm 1.41^{\mathrm{b}}$ & $19.71 \pm 1.24^{\mathrm{a}}$ & $25.92 \pm 1.57^{b}$ \\
\hline $80 \mathrm{mg} / \mathrm{kg}$ & $2.02 \pm 0.43^{\mathrm{a}, \mathrm{b}}$ & $12.63 \pm 1.64^{\mathrm{a}, \mathrm{b}}$ & $10.15 \pm 0.85^{\mathrm{a}, \mathrm{b}}$ \\
\hline $\mathrm{CQ}(5 \mathrm{mg} / \mathrm{kg})$ & $9.17 \pm 1.21^{\mathrm{a}}$ & $18.10 \pm 0.52$ & $16.59 \pm 1.10^{\mathrm{a}}$ \\
\hline
\end{tabular}

Values are mean \pm S.E.M., $n=5 ;{ }^{*} p<0.05$ vs. control.

a Significantly different from control at $p<0.05$.

${ }^{\mathrm{b}}$ Significantly different from $\mathrm{CQ}$ at $p<0.05$. 